\title{
THIS BIG
}

\author{
A ray of hope.
}

\section{BY JOHN COOPER HAMILTON}

$I$ should kill them all ... What? We're transmitting?

1 Greetings, fellow researchers, wherever you are. Important news! In my laboratory earlier this week. I - Really? Oh, very well.

I have just been advised to begin with a joke. This card?

What is red - this is a riddle - what is red shading gradually to a frothy transparency and travels at 4,300 r.p.m.? Answer: a graduate student in a Pelsen 557VES centrifuge! But you can only fit them in 300 millilitres at a time! Pause for laughter.

Laugh, damn you, laugh! Fire will rain down on your cities and your sewers will fill with a million angry - Now what? Oh. Of course, you're correct.

Ahem. Yes. What happened in my laboratory was a third case of spontaneous human combustion, henceforth SHC.

Funny story: it was Osgood, one of my graduate students. Osgood, Max and I sat down to eat our bag lunches in the break room. I had onomi sashimi, which is fresh blue-whale meat. I know, I know! It's terrible, but I have it with a side of brown rice rather than white. That's healthier. Max had a banana, as is traditional. Osgood pulled a thermos of coffee from his bag, said, "Would you like some?" and burst into flames.

Oh, how we laughed!

Well, I did. Max scampered off for a fire extinguisher and Osgood rather uselessly thrashed about and screamed. He lost control so far as to approach me, at which point I shot him with the harpoon gun handily sitting nearby. I directed Max to extinguish the flames, but only after preparing an impromptu banana flambé.

A recipe shall follow this broadcast.

Max said, "That was the second this week." I said, "No, dear friend, that was actually number three." Ouch.

Excuse me. I said, "Max, that was the second this week." He said, "No, the third."

I enjoy mentoring, but with Osgood's exit my island was out of mentees. Before obtaining more, it behooved me to ascertain the cause of Osgood's death. The cause of SHC, I mean. The cause of Osgood's death was a harpoon in the head.

\section{$\rightarrow$ NATURE.COM}

Follow Futures:

y @NatureFutures

f go.nature.com/mtoodm
My first thought was a matter/contramatter reaction - I had several difficulties repurposing my largest collider into a cappuccino machine. But a little noodling demonstrated that a reaction would have resulted in an explosion of approximately 3,140 megatons. Or, actually, 3,129, deducting the $300 \mathrm{ml}$ of matter used in the previous day's experiment.

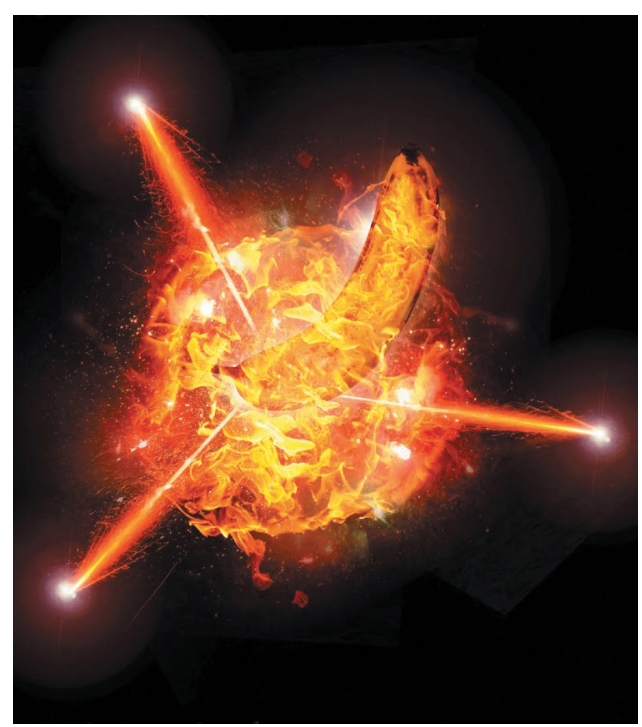

Such an explosion would have utterly destroyed my secret island base. It might even have cracked a tectonic plate, but that's a thought for another day. The point is, it wasn't contra-matter.

Other SHC investigations:

My new hot sauce. False: 50\% toxic dose at 2.1 grams, but no amusing side effects.

The British super-spy in the holding cell. False: he'd escaped and was no longer on the island.

The experimental RF resonant cavity thruster, or 'EMDrive'. False: it's identical to the model being debunked by NASA, and it does absolutely nothing. I also checked my in-use EMDrive and observed nothing unexpected.

I admit, fellow researchers, that I despaired and took to the consolation of work. This month's project was developing a new neutrino detector. Traditional models, created by traditional so-called scientists at their hide-bound universities where they will rue the day! Rue the day they threw me out and called me mad! Me? Mad!!! Ouch. Thank you, Max.

As I was saying, current detector designs use mineral-oil-filled tanks, hundreds of metres long, to detect the elusive particles. Ha! Again, I say ha!
It was - and is! - my theory that, owing to the principle of resonance, a tank the same size as a neutrino will detect particles just as efficiently. Dozens of mineral-oil-filled tanks were arranged before my shrink ray, a standard RH 1050 model, more than capable of reducing a tank to subatomic size. A laboratory fire - graduate student number 1 had disrupted the procedure and the tanks now varied in size. The one before me was something over two metres in diameter at the moment it exploded.

I was lying right here, on the very infirmary bed from which I now broadcast, when I awoke and said, "Max, I’ve got it! The resonance theory is right, and contact is energetic enough to translate the neutrino's mass into heat!" Ouch. Damn your furry little hide, Max.

I was lying right here on the infirmary bed when I awoke, and Max said, "Doc, I've got it! Your resonance theory is right!" Et cetera.

While I was unconscious, Max, a very capable assistant, I freely admit - Now put that damned knife down - achieved confirmation of the theory. Neutrinos are really this big.

I'm holding my arms all the way apart. That big.

Need I remind my august peers that extraordinary claims require extraordinary evidence? The idea that the entire range of subatomic particles is actually vanishingly small doesn't pass the mad-laugh test. It was an assumption made by our small-minded brethren. They forced us into hiding, into - outside the annual conference at Cabo communicating only via scrambled radio transmissions.

They shall pay dearly for their lack of vision.

Neutrinos are not small and common. They are large and rare. Detector tanks shrunk to exactly one and a half diameters refracted neutrinos through my laboratory at a furious rate, causing SHC. Focused, the neutrinos create lethal beams capable of spanning any distance, penetrating any armour.

Rise, brothers and sisters, rise! I've dibs on the basic deathbeam patent, but there shall be enough death, and enough beams, for all! -

John Cooper Hamilton writes humorous genre fiction, except when it's sombre or creepy. He even writes literary fiction if he thinks he can get away with it. 